\title{
Water Pollution from the Activity of Large-Ruminant Animal Quarantine Installation (AQI) in Its Receiving Water Body
}

\author{
N. Zainuddin ${ }^{\mathrm{a}, *}$, M.S. Maarif ${ }^{\mathrm{b}}$, E. Rianic ${ }^{\mathrm{c}}$ \& S.M. Noor ${ }^{\mathrm{d}}$ \\ aDepartment of Management Natural Resources and Environment, Bogor Agricultural University \\ Kampus IPB Darmaga Bogor 16680, Indonesia \\ ${ }^{\mathrm{b} B u s i n e s s}$ School, Bogor Agricultural University \\ Gedung SB IPB - Kampus IPB Gunung Gede, Jalan Raya Pajajaran, Bogor 16151, Indonesia \\ 'Department Management of Resources Fisheries, Faculty of Fisheries and Marine, Bogor Agricultural University \\ Kampus IPB Darmaga Bogor 16680, Indonesia \\ ${ }^{\mathrm{d}}$ Indonesian Research Center for Veterinary Sciences, Indonesian Agency for Agricultural Research and \\ Development, Ministry of Agriculture \\ Jalan RE. Martadinata No. 30, Bogor 16114, Indonesia \\ *Corresponding author: nuryanizainuddin@yahoo.com \\ (Received 18-05-2018; Revised 28-11-2018; Accepted 17-12-2018)
}

\begin{abstract}
Indonesia governs the post-entry observation through the Animal Quarantine Installation (AQI) as a precautionary measure to minimize the risk of the entrance and the spread of animal infectious organism and disease of import animals. However, wastes generated from their activities are potentially pollute the environment. This research aimed to evaluate the pollution from AQI activity on its receiving water body. The study was conducted at 5 companies as follow: PT. A, PT. B, PT. C, PT. D, and PT. E. The samples were taken from their wastewater and the river where the waste was discarded with two replications. Direct measurement was carried out in the field by using water quality equipment to analyze $\mathrm{pH}$, temperature, DO, and TDS. For other analysis, samples collected were preserved in refrigerator at $4{ }^{\circ} \mathrm{C}$ before laboratory testing was carried out to minimize microbiological decomposition of solids. Pollution variabels were analyzed by analysis of variance test (ANOVA) with $95 \%$ confidence level followed by turkey test. The results showed that there was no difference in pollution from temperature, DO, TDS, TSS, COD, and ammonia variables from 5 companies. In contrast, two variables i.e., $\mathrm{pH}$ and BOD indicating the difference among 5 companies $(\mathrm{P}<0.05)$. In conclusion, the results of wastewater variables from large-ruminant $A Q I$ activity were generally exceeding the Quality Standard of Wastewater for cattle-farming. Thus there is a pollution of water bodies in the environment around AQI due to their activities.
\end{abstract}

Keywords: animal quarantine installation; large-ruminant; water body; water pollution

\section{INTRODUCTION}

Import volumes of cattle are increase from year to year with a rate of about 3\% per year during the last four years (Barantan, 2017). Global farm-animal business from trade, exchange, to distribution will open up the possibility of the dangerous and infectious animal diseases that potentially damage the natural resources. Many pathogens capable of infecting humans can be found in animal feces and the feces from these animals have a great potential to produce a currently unquantified-though likely substantial-risk to human health (Delahoy et al., 2018). Related with this issue, the regulation No. 16/1992 of Indonesian Agricultural Quarantine Agency (IAQA) becomes the front guard to prevent the entries and spreading of animal diseases into the territory of the Republic of Indonesia, the spread of animal diseases from one area to the area in Indonesian territory, and also the spreading of animal diseases from the territory of the Republic of Indonesia. Therefore, the IAQA carries out a careful handling based on the technical norms in order to prevent the health risk of domestic livestock as well as human health from infectious animal diseases threat that are zoonotic. Animals found in close proximity to humans in low-and middle-income countries (LMICs) harbor many pathogens capable of infecting humans, transmissible via their feces (Delahoy et al., 2018).

Technical measure of the cattle import activity is during 14 days of quarantine period or specified time as extended (depend on the post-entry observed at Animal Quarantine Installation). Animal Quarantine Installation (AQI) as regulation no 70/2015 is an entire building, including the equipment, land, and supporting facilities. All of these technical requirements must be completed as their interests as quarantine measure areas. AQI do quarantine measures to some carrier subject before their entry with the character of a high risk carrier, requiring 
the effective quarantine measures, requiring certain and further treatment. Based on the ownership, there are two kinds of AQI, the government-owned and the private-owned which are regulated by the legal terms. AQIs owned by the government are currently amounts to 23, whereas the private-owned AQI amount to 57 (all of them are legalized by the IAQA, also audited and supervised for its feasibility) which spread throughout Indonesia.

Annual report by IAQA in 2016 recorded the extermination of three imported-cattle infected with Johne's Disease which entered Indonesia through the AQI Palangkaraya Quarantine Station. Besides, two imported cattle from Australia that were positive for brucellosis which was known as one of the zoonotic diseases also found at AQI Lampung Quarantine Station (Barantan, 2016). Research by Danial et al. (2010), mentioned about 60 urine samples of cattle imported from Australia in AQI were positive Trenbolone acetate (TBA) hormones residue with various concentrations. The concentration of residual TBA hormones $<2$ ppb were detected in 37 samples $(61.67 \%)$, the residual concentration of TBA hormones at the range of 2-4 ppb were detected in 7 samples $(7 \%)$, and the concentration of residual TBA hormones $>4 \mathrm{ppb}$ were detected in 16 samples $(26.67 \%)$. According to Lange et al. (2002), 70\% of the total secretion of estrogen hormone can be released along with the feces, whereas the secretion of growth hormone can be released with the urine (Tilahun et al., 2016). In addition, treatment during quarantine period uses antibiotics thus potentially causes the environmental pollution by the antibiotics (Ho et al., 2012).

AQI is a farming system with a high level of biosecurity to prevent the spread of animal disease. Previous research described the possibility of carrying over pathogenic microorganisms and toxic chemicals into the environment through wastewater of the farms. Improper waste management can predispose to carrying pathogenic microorganisms and chemical toxins to the surrounding environment. It can be seen that the pollution of the organic materials from AQI activities into the environment and water bodies has not been observed. Research on testing the quality standards of wastewater in AQI according to wastewater quality standard for cattle-farming (KLHK, 2014) and Water quality standard of water surface (KLHK, 2001) for AQI waste water is never done. Therefore, it is necessary to conduct a research about the pollution from the AQI activity on the receiving water body, so that wastes management would become sustainable. The purpose of this study is to evaluate the potential of water pollution from AQI activity on its receiving water body.

\section{MATERIALS AND METHODS}

This study was conducted from SeptemberDecember 2017 at 5 locations of PT. A, PT. B, PT. C, PT. D, and PT. E in Java and Sumatra. Samples collected were preserved in refrigerator at $4{ }^{\circ} \mathrm{C}$ before laboratory testing was carried out to minimize microbiological decomposition of solids. Variables measured consisted of $\mathrm{pH}$, temperature, dissolve oxygen (DO), total dis- solved solid (TDS), total suspended solid (TSS), biochemical oxygen demand (BOD), chemical oxygen demand (COD), ammonia $\left(\mathrm{NH}_{3}-\mathrm{N}\right)$, Coliform, E. coli, and Salmonella $s p$. Direct measurement was carried out in the field by using water quality equipment (Horiba $U$ 52) to analyze $\mathrm{pH}$, temperature, DO, and TDS. Sampling was performed at 5 point locations each with criteria: 1) The closest location from the cages, 2) Location between cages and storage pond (IPAL), 3) Location inside the storage pond (IPAL), 4) Location on the water body of the river which receives wastewater input from storage pond outlet, and 5) Location on the upstream river from the waste disposal site. However, the sampling points in the field were adjusted based on the situation and conditions, as shown in Table 2 to Table 6 .

TSS was measured by using APHA 22 ${ }^{\text {nd }}$ (2012): 2540-Solids D method, BOD was measured by using APHA 22 ${ }^{\text {nd }}(2012): 5210$ B method, COD was measured by using APHA 22 nd (2012): 5220 C method, and ammonia was measured by using APHA 22 ${ }^{\text {nd }}(2012)$ : 4500-NH3 F method. All tests were carried out at the Integrated Laboratory, Bogor Agricultural University. Coliform and E. coli bacteria were detected by using Indonesia National Standards (SNI 01-2332.1-2006), and Salmonella $s p$ was detected by using SNI 01-2332.22006 method. All bacteriological testings were conducted at the Center of Diagnostic Standard Agriculture Quarantine.

The sample was taken twice from each company. Data were analyzed by variants analysis with 95\% confidence level to determine the difference in each pollution variable of each company. If there were differences, a Turkey test was performed as a further analysis. The hypothesis of this research was that there was no difference in each variables pollution from each AQI company (H0) and there were differences in each variables pollution from each AQI company (H1).

The data on wastewater quality from each AQI were described descriptively according to the condition of each AQI location. These data were compared with the quality standards of wastewater for cattle-farm activities on KLHK (2014) and the government regulation in Water Quality Management and Water Pollution Control, arranged on KLHK (2001).

\section{RESULTS}

The activity inside the AQI generates the wastes and wastewater. In this study, the management of wastes was handling properly with the utilization of the feces to make compost. However, the situation was different in handling the wastewater which mostly very badly or poor. Some AQI even discharged the wastewater directly into the water bodies without any proper process. The results showed that most of the $\mathrm{pH}$ values of wastewater samples were low. In addition, the results of TSS, BOD, COD, ammonia, E. Coli, and coliform measurements were high, but Salmonella $s p$ was undetected.

A good $\mathrm{pH}$ value was only found in the sample from PT E. The average value of TSS was the only measurement from PT B giving results that met the wastewater quality standards $(<100)$. The results of 
BOD, COD, and ammonia measurements exceeded the wastewater quality standard (> 100) in almost all AQI as were shown in Table 1 . The wastewater was also detected to contain E. coli and coliform because there was a possibility that the wastewater was contaminated by the feces and mix with the urine. Salmonella $s p$ was not detected in the wastewater from all AQIs measured. The results showed that the quality of the water in the river was not good and contaminated by anthropogenic waste at the upstream of the river.

The results of analysis of variance showed that there was no difference in pollution from temperature, DO, TDS, TSS, COD, and ammonia variables from 5 companies sampled. These results were in contrast to $\mathrm{pH}$ and BOD variables which showed the significant differences among 5 companies $(\mathrm{P}<0.05)$. The result of analysis of variance are shown in Table 1 . The results complete of water variables are shown in Table 2 until Table 6 .

\section{DISCUSSION}

The biosecurity system in AQI must be more stringent because it is used to prevent the entry, exit, and spread of animal diseases when handling the imported livestock. AQI can easily pollute the surrounding en- vironment if it does not have a proper waste treatment system. From this study, it was found that almost all of the average $\mathrm{pH}$ values of AQI were smaller $(<6)$ than the wastewater quality standards, except AQI of PT E.

PT. A is an AQI owned by the private locates in Cariu, Bogor Regency. The wastes are processed into a manure compost for further sale commercially. Meanwhile, the wastewater is collected in storage pond with an aeration system without flowing them into the river, so there were only three sampling points in this site. Wastewater variables of PT. A can be seen in Table 2.

The result of wastewater variables on three sampling points exceeded the water quality standard (Table 2). The $\mathrm{pH}$ values and DO were higher towards the downstream while the value of TSS, BOD, and COD were lower towards the downstream. These conditions were caused by the contents of wastewater. The wastewater contained highly organic materials, so the more active process was decompositions. The more active decomposition resulted in a high $\mathrm{CO}_{2}$ production, lower acidity, and lower oxygen solubility. The $\mathrm{pH}$ of wastewater significantly increased from location I to III (Table 2) and this result was in line with the results reported by Mansyur \& Choi (2011) that the pH increased gradually during storage periods. This condition is caused by the

Table 1. Pollution indicator values of each variables from each animal quarantine installation company

\begin{tabular}{lcccccc}
\hline \multicolumn{1}{c}{ Variables } & \multirow{2}{*}{ Unit } & \multicolumn{5}{c}{ Company } \\
\cline { 3 - 8 } & & $\mathrm{A}$ & $\mathrm{B}$ & $\mathrm{C}$ & $\mathrm{D}$ & $\mathrm{E}$ \\
\hline Temperature & ${ }^{\circ} \mathrm{C}$ & $31.78 \pm 0.53$ & $31.4 \pm 2.09$ & $32.11 \pm 1.3$ & $31.15 \pm 0.51$ & $32.1 \pm 0.09$ \\
$\mathrm{pH}$ & & $4.54 \pm 0.90^{\mathrm{a}}$ & $4.11 \pm 0.24^{\mathrm{a}}$ & $3.99 \pm 0.80^{\mathrm{a}}$ & $4.83 \pm 0.81^{\mathrm{a}}$ & $8.23 \pm 0.21^{\mathrm{b}}$ \\
Dissolve oxygen (DO) & $\mathrm{mg} / \mathrm{L}$ & $2.88 \pm 0.34$ & $2.21 \pm 0.42$ & $2.21 \pm 0.57$ & $2.77 \pm 0.44$ & $2.87 \pm 0.16$ \\
Total dissolved solid (TDS) & $\mathrm{g} / \mathrm{l}$ & $1.27 \pm 0.21$ & $0.79 \pm 0.65$ & $0.54 \pm 0.66$ & $1.09 \pm 0.33$ & $1.23 \pm 0.14$ \\
Total suspended solid (TSS) & $\mathrm{mg} / \mathrm{L}$ & $113.00 \pm 43.00$ & $73.20 \pm 78.59$ & $264.00 \pm 203.29$ & $128.20 \pm 45.60$ & $179.44 \pm 61.90$ \\
Biochemical oxygen demand & $\mathrm{mg} / \mathrm{L}$ & $244.20 \pm 19.89^{\mathrm{a}}$ & $107.65 \pm 153.61^{\mathrm{a}}$ & $219.36 \pm 300.13^{\mathrm{a}}$ & $160.87 \pm 134.03^{\mathrm{a}}$ & $826.45 \pm 114.52^{\mathrm{b}}$ \\
(BOD) & & & & & & \\
Chemical oxygen demand & $\mathrm{mg} / \mathrm{L}$ & $828.28 \pm 234.27$ & $898.58 \pm 1260.79$ & $1078.25 \pm 1251.33$ & $1445.98 \pm 1288.86$ & $2025.07 \pm 1252.82$ \\
(COD) & & & & & & \\
Ammonia $\left(\mathrm{NH}_{3}-\mathrm{N}\right)$ & $\mathrm{mg} / \mathrm{L}$ & $89.17 \pm 8.85$ & $37.48 \pm 58.69$ & $55.12 \pm 27.41$ & $60.44 \pm 34$ & $28.88 \pm 3.85$ \\
\hline
\end{tabular}

Note: means in the same row with different superscripts differ significantly $(\mathrm{P}<0.05)$.

Table 2. The average wastewater and its receiving water body variables of PT. A

\begin{tabular}{|c|c|c|c|c|c|c|}
\hline \multirow{2}{*}{ Variables } & \multirow{2}{*}{ Unit } & \multicolumn{3}{|c|}{ Sampling point location } & \multirow{2}{*}{$\begin{array}{c}\text { Waste water } \\
\text { QS* }^{*}\end{array}$} & \multirow{2}{*}{$\begin{array}{c}\text { Water river } \\
\mathrm{QS}^{* *}\end{array}$} \\
\hline & & $\mathrm{I}$ & II & III & & \\
\hline Temperature & ${ }^{\circ} \mathrm{C}$ & 32.11 & 31.17 & 32.05 & & $3^{\circ}$ deviation \\
\hline $\mathrm{pH}$ & & 3.5 & 5.02 & 5.1 & $6-9$ & $6-9$ \\
\hline Dissolve oxygen (DO) & $\mathrm{mg} / \mathrm{L}$ & 2.51 & 3.18 & 2.96 & & 4 \\
\hline Total dissolved solid (TDS) & $\mathrm{g} / \mathrm{l}$ & 1.17 & 1.13 & 1.52 & & 1000 \\
\hline Total suspended solid (TSS) & $\mathrm{mg} / \mathrm{L}$ & 126 & 148 & 65 & 100 & 50 \\
\hline Biochemical oxygen demand (BOD) & $\mathrm{mg} / \mathrm{L}$ & 265.3 & 225.8 & 241.5 & 100 & 3 \\
\hline Chemical oxygen demand (COD) & $\mathrm{mg} / \mathrm{L}$ & 1012.67 & 907.5 & 564.67 & 200 & 25 \\
\hline Ammonia $\left(\mathrm{NH}_{3}-\mathrm{N}\right)$ & $\mathrm{mg} / \mathrm{L}$ & 79.05 & 93 & 95.47 & 25 & - \\
\hline Coliform & $\mathrm{MPN} / \mathrm{mL}$ & & & 1000 & & 1000 \\
\hline E. coli & $\mathrm{MPN} / \mathrm{mL}$ & & & 100 & & 5000 \\
\hline Salmonella sp & & & & Negative & & \\
\hline
\end{tabular}

Note: $\mathrm{I}=$ The closest location from the cages; II= Location between cages and storage pond; III= Location inside the storage pond. * Quality standard of wastewater for cattle-farming (KLHK, 2014); ${ }^{* *}$ Quality standard of water surface (KLHK, 2001). 
Table 3. The average wastewater and its receiving water body variables of PT. B

\begin{tabular}{|c|c|c|c|c|c|c|c|c|}
\hline \multirow{2}{*}{ Variables } & \multirow{2}{*}{ Unit } & \multicolumn{5}{|c|}{ Sampling point location } & \multirow{2}{*}{$\begin{array}{c}\text { Waste } \\
\text { water QS* }\end{array}$} & \multirow{2}{*}{$\begin{array}{c}\text { Water river } \\
\text { QS** }^{* *}\end{array}$} \\
\hline & & $\mathrm{I}$ & II & III & IV & V & & \\
\hline Temperature & ${ }^{\circ} \mathrm{C}$ & 33.60 & 31.18 & 30.89 & 30.91 & 30.42 & & $3^{\circ}$ deviation \\
\hline $\mathrm{pH}$ & & 4.00 & 4.00 & 4.00 & 4.00 & 4.54 & $6-9$ & $6-9$ \\
\hline Dissolved oxygen (DO) & $\mathrm{mg} / \mathrm{L}$ & 2.78 & 2.25 & 1.60 & 2.10 & 2.30 & & 4 \\
\hline Total dissolved solid (TDS) & $\mathrm{g} / \mathrm{l}$ & 0.012 & 1.41 & 1.22 & 1.15 & 0.169 & & 1000 \\
\hline Total suspended solid (TSS) & $\mathrm{mg} / \mathrm{L}$ & 174 & 142 & 28 & 7 & 15 & 100 & 50 \\
\hline $\begin{array}{l}\text { Biochemical oxygen demand } \\
\text { (BOD) }\end{array}$ & $\mathrm{mg} / \mathrm{L}$ & 182.59 & 344.89 & 6 & 2.8 & $<2$ & 100 & 3 \\
\hline $\begin{array}{l}\text { Chemical oxygen demand } \\
\text { (COD) }\end{array}$ & $\mathrm{mg} / \mathrm{L}$ & 1701.72 & 2738.40 & 23.47 & 15.65 & 13.68 & 200 & 25 \\
\hline Ammonia $\left(\mathrm{NH}_{3}-\mathrm{N}\right)$ & $\mathrm{mg} / \mathrm{L}$ & 134 & 53.32 & 0.03 & 0.02 & 0.02 & 25 & - \\
\hline Coliform & $\mathrm{MPN} / \mathrm{mL}$ & & & & & 100 & & 1000 \\
\hline E. coli & $\mathrm{MPN} / \mathrm{mL}$ & & & & & 10 & & 5000 \\
\hline Salmonella sp & & & & & & Negative & & \\
\hline
\end{tabular}

Note: $\mathrm{I}=$ The closest location from the cages; II= Location between cages and storage pond; III= Location inside the storage pond; IV= Location on the water body of the river which receives wastewater input from storage pond outlet; $\mathrm{V}=$ Location on the upstream river from the outlet of waste disposal. * Quality standard of wastewater for cattle-farming (KLHK, 2014); ${ }^{* *}$ Quality standard of water surface (KLHK, 2001).

Table 4. The average wastewater and its receiving water body variables of PT. C

\begin{tabular}{|c|c|c|c|c|c|c|c|}
\hline \multirow{2}{*}{ Variables } & \multirow{2}{*}{ Unit } & \multicolumn{4}{|c|}{ Sampling point location } & \multirow{2}{*}{$\begin{array}{c}\text { Waste } \\
\text { water QS* }\end{array}$} & \multirow{2}{*}{$\begin{array}{c}\text { Water river } \\
\mathrm{QS}^{* *}\end{array}$} \\
\hline & & $\mathrm{I}$ & II & III & IV & & \\
\hline Temperature & ${ }^{\circ} \mathrm{C}$ & 33.03 & 30.85 & 33.41 & 31.15 & & $3^{\circ}$ deviation \\
\hline $\mathrm{pH}$ & $\mathrm{pH}$ & 4.41 & 4.39 & 4.37 & 2.79 & $6-9$ & $6-9$ \\
\hline Dissolved oxygen (DO) & $\mathrm{mg} / \mathrm{L}$ & 2.98 & 2.24 & 1.62 & 2.01 & & 4 \\
\hline Total dissolved solid (TDS) & $\mathrm{g} / 1$ & 0.002 & 1.36 & 0.801 & 0.011 & & 1000 \\
\hline Total suspended solid (TSS) & $\mathrm{mg} / \mathrm{L}$ & 191 & 163 & 567 & 135 & 100 & 50 \\
\hline Biochemical oxygen demand (BOD) & $\mathrm{mg} / \mathrm{L}$ & 669.50 & 65.93 & 65.93 & 76.07 & 100 & 3 \\
\hline Chemical oxygen demand (COD) & $\mathrm{mg} / \mathrm{L}$ & 2894.88 & 179.95 & 909.54 & 328.61 & 200 & 25 \\
\hline Ammonia $\left(\mathrm{NH}_{3}-\mathrm{N}\right)$ & $\mathrm{mg} / \mathrm{L}$ & 80.06 & 34.09 & 77.48 & 28.85 & 25 & - \\
\hline Coliform & $\mathrm{MPN} / \mathrm{ml}$ & & & & 10000 & & 1000 \\
\hline E. coli & $\mathrm{MPN} / \mathrm{ml}$ & & & & 10 & & 5000 \\
\hline Salmonella sp & & & & & Negative & & \\
\hline
\end{tabular}

Note: I= Location inside the storage pond and closest from the cages; II=Location inside the storage pond, far from the cages and close to the outlet; III= Location on the water body of the river which receives wastewater input from storage pond outlet; IV= Location on the upstream river from the outlet of waste disposal. * Quality standard of wastewater for cattle-farming (KLHK, 2014); ** Quality standard of water surface (KLHK, 2001).

Table 5. The average wastewater and its receiving water body variables of PT. D

\begin{tabular}{|c|c|c|c|c|c|c|c|c|}
\hline \multirow{2}{*}{ Variables } & \multirow{2}{*}{ Unit } & \multicolumn{5}{|c|}{ Sampling point location } & \multirow{2}{*}{$\begin{array}{c}\text { Waste } \\
\text { water QS* }\end{array}$} & \multirow{2}{*}{$\begin{array}{c}\text { Water river } \\
\mathrm{QS}^{* *}\end{array}$} \\
\hline & & I & II & III & IV & $\mathrm{V}$ & & \\
\hline Temperature & ${ }^{\circ} \mathrm{C}$ & 31.32 & 30.46 & 31.8 & 30.85 & 31.32 & & $3^{\circ}$ deviation \\
\hline $\mathrm{pH}$ & & 3.90 & 4.08 & 5.28 & 5.78 & 5.12 & $6-9$ & $6-9$ \\
\hline Dissolved oxygen (DO) & $\mathrm{mg} / \mathrm{L}$ & 2.83 & 3.05 & 2.97 & 3.00 & 2.00 & & 4 \\
\hline Total dissolved solid (TDS) & $\mathrm{g} / \mathrm{l}$ & 1.18 & 0.613 & 1.54 & 1.07 & 1.05 & & 1000 \\
\hline Total suspended solid (TSS) & $\mathrm{mg} / \mathrm{L}$ & 126 & 148 & 65 & 113 & 189 & 100 & 50 \\
\hline $\begin{array}{l}\text { Biochemical oxygen demand } \\
\text { (BOD) }\end{array}$ & $\mathrm{mg} / \mathrm{L}$ & 243.40 & 344.89 & 142.01 & 45.65 & 28.40 & 100 & 3 \\
\hline $\begin{array}{l}\text { Chemical oxygen demand } \\
\text { (COD) }\end{array}$ & $\mathrm{mg} / \mathrm{L}$ & 1160.95 & 2041.67 & 3362.75 & 496.41 & 168.14 & 200 & 25 \\
\hline Ammonia $\left(\mathrm{NH}_{3}-\mathrm{N}\right)$ & $\mathrm{mg} / \mathrm{L}$ & 69.03 & 89 & 93.47 & 34.87 & 15.84 & 25 & - \\
\hline Coliform & $\mathrm{MPN} / \mathrm{mL}$ & & & & & 10000 & & 1000 \\
\hline E. coli & $\mathrm{MPN} / \mathrm{mL}$ & & & & & 1000 & & 5000 \\
\hline Salmonella sp & & & & & & Negative & & \\
\hline
\end{tabular}

Note: $\mathrm{I}=$ The closest location from the cages; II= Location between cages and storage pond; III= Location inside the storage pond; IV= Location on the water body of the river which receives wastewater input from storage pond outlet; V= Location on the upstream river from the outlet of waste disposal. * Quality standard of wastewater for cattle-farming (KLHK, 2014); ${ }^{* *}$ Quality standard of water surface (KLHK, 2001). 
Table 6. The average wastewater and its receiving water body variables of PT. E

\begin{tabular}{|c|c|c|c|c|c|c|}
\hline \multirow{2}{*}{ Variables } & \multirow{2}{*}{ Unit } & \multicolumn{3}{|c|}{ Sampling point location } & \multirow{2}{*}{$\begin{array}{c}\text { Wastewater } \\
\text { QS* }\end{array}$} & \multirow{2}{*}{$\begin{array}{c}\text { Water river } \\
\text { QS }^{* *}\end{array}$} \\
\hline & & $\mathrm{I}$ & II & III & & \\
\hline Temperature & ${ }^{\circ} \mathrm{C}$ & 32.2 & 32.04 & 32.05 & & $3^{\circ}$ deviation \\
\hline $\mathrm{pH}$ & & 8.3 & 8.4 & 8.0 & $6-9$ & $6-9$ \\
\hline Dissolved oxygen (DO) & $\mathrm{mg} / \mathrm{L}$ & 2.71 & 3.03 & 2.86 & & 4 \\
\hline Total dissolved solid (TDS) & $\mathrm{g} / \mathrm{l}$ & 1.07 & 1.31 & 1.32 & & 1000 \\
\hline Total suspended solid (TSS) & $\mathrm{mg} / \mathrm{L}$ & 171.33 & 122 & 245 & 100 & 50 \\
\hline Biochemical oxygen demand (BOD) & $\mathrm{mg} / \mathrm{L}$ & 892.57 & 694.22 & 892.57 & 100 & 3 \\
\hline Chemical oxygen demand (COD) & $\mathrm{mg} / \mathrm{L}$ & 1320.70 & 1282.96 & 3471.54 & 200 & 25 \\
\hline Ammonia $\left(\mathrm{NH}_{3}-\mathrm{N}\right)$ & $\mathrm{mg} / \mathrm{L}$ & 30.04 & 32.02 & 24.59 & 25 & - \\
\hline Coliform & $\mathrm{MPN} / \mathrm{mL}$ & & & 1000 & & 1000 \\
\hline E. coli & $\mathrm{MPN} / \mathrm{mL}$ & & & 100 & & 5000 \\
\hline Salmonella sp & & & & Negative & & \\
\hline
\end{tabular}

Note: I= Location on the ditch with the closets distance from the cages; II= Location on the ditch with the furthest distance from the cages and close from the outlet; III= Location on the water body of the river which receives wastewater input from the ditch outlet. * Quality standard of wastewater for cattle-farming (KLHK, 2014); ${ }^{* *}$ Quality standard of water surface (KLHK, 2001).

degradation of some intermediate compounds that are emitted to the atmosphere (Mansyur \& Choi, 2011).

DO are also used to degrade the organic material in aquatic ecosystems. According to Deb \& Shukla (2011), who stated that dissolved oxygen was needed for decomposition and oxidation of organic matter. COD in wastewater has the highest value compared to the other points, and the amount is almost four times the BOD. This condition is due to the use of hard-to-degrade material such as the growth hormone from cattlefarming activity and the anti-microbial (Ho et al., 2012; Bartelt-Hunt et al., 2011) thus contaminating the soil and is positively detected by the hormone of estrogen group (Goeppert et al., 2014). Endogenous hormones of animal origin have been released and deposited in the environmental for thousands of years; however, recent years have seen a significant increase due to the increasing population and more intensive farming practices (Lange et al., 2002). The synthetic growth promoters used over the last five decades to improve animal production performance exhibit a high chemical stability and low deactivation via biotransformation, and may thus affect the ecological balance due to their prolonged persistence in the environment. Estrogen, testosterone, 4-androstenedione, and androsterone have been detected in wastewater derived from pig farms at concentrations ranging from 30 to $3600 \mathrm{ng} / \mathrm{L}$ (Bartelt-Hunt et al., 2011).

Location I has the lowest concentration of ammonia because of unperfect or incomplete decomposition of organic materials. Therefore, the amount of ammonia in wastewater in location I is lower compared to those in the downstream location. The accumulation of feces in the wastewater gives the microorganisms time to decompost the solid materials to produce ammonia gas, nitrite, nitrate, and sulfide acid. Location 1 was a location closest to the cage while sampling was carried out when the cage was being cleaned with water, so there was a high possibility of dilution of ammonia. This condition is occurred in this study.

Without any wastewater disposal into the river, it was found that there was relatively no contamination of water bodies from the activities of PT. A. However, the high accumulation of organic matter in the storage pond resulted in the high decomposition of these organic materials producing a higher number of ammonia that eventually reduce the environmental aesthetics. The high concentration of ammonia causes the air pollution and smells badly. In the beginning, the location of AQI was arranged far from the residential. The high rate of population growth resulted in a high demand for housing and residential development that causes the AQI is closer to the residential location. The result of interviews mentioned that the community was uncomfortable with the air pollution.

The wastewater was also detected for containing E. coli and coliform. The contamination of wastewater with these microbes could be caused by the contamination of feces which commonly contain E. coli bacteria (Stehfest et al., 2013; Damanik, 2014). Based on the report of Givens et al. (2016), hepatitis E virus was found in surface water following manure application. It was expected that the wastewater would not contaminate the body water or even the resident wells where had around $500 \mathrm{~m}$ distance. Salmonella $\mathrm{sp}$ were not detected so that there was no concern of pathogen contaminant in the water around PT. A. Even though the parameters measured exceeded the values of standard quality and the existence of air pollution, the condition would relatively safe for the environment as it was existed for a long time.

PT. B locates in Lampung and is owned by the private. The feces waste in this AQI was collected for reuse as a raw manure. The wastewater was derived from urine and dirty water from the washing the cage. Wastewater variables of sampling points in locations I and II exceeded the quality standard, while the value of TSS, BOD, COD, and ammonia on location III were under the quality standard (Table 3). All results of $\mathrm{pH}$ values in locations I, II, and III were 4. A proper handling across the storage pond tended to cause the good result in wastewater variables as was seen during the field visit. CODs in wastewater were ten times higher 
than BOD. This good condition was suspected derived from the use of hard-to-degrade material such as the trenbolone (Danial et al., 2010) and the use of various antibiotics for the prevention and treatment (Pinheiro et al., 2013).

In case of the use of drugs and hormones which would be secreted and released through the urine, this condition would make that the COD were 10 times higher than BOD and the BOD value was the lowest among the other sites locations. Similar to the values of TSS, COD, and ammonia were high results. The high results were associated with the lower topographical location that would get a greater amount of the run-off water and organic materials. This condition would create the accumulation of organic material in point location II that would result in a higher concentration of ammonia.

The good results in point location III (storage pond) with the lower value of TSS, BOD, COD, and ammonia were expected because the better performed of waste handling. In addition, there were Lemna sp. covering almost the entire surface of storage pond. According to Amalia et al. (2014), Lemna sp. was able to effectively reduce nitrogen and phosphate. Borguini et al. (2013) stated that Lemna perpusilla had the ability to deal with the waste of hazardous and toxic materials such as heavy metals, organic substances, and inorganic substances. Research by El Kheir et al. (2007) was mentioned that Lemna gibba could reduce nitrogen and phosphate level from each $8.32 \mathrm{mg} / \mathrm{L}$ and $11 \mathrm{mg} / \mathrm{L}$ to $0 \mathrm{mg} / \mathrm{L}$ and $6.2 \mathrm{mg} / \mathrm{L}$. Research by Sutrisno et al. (2010) on household waste handling resulted in Lemna minor ability to reduce BOD up to $76.54 \%$ and COD up to $72.44 \%$. Based on research by Sutrisno et al. (2010), the presence of Lemna sp in location III might cause a decrease in ammonia concentration in waste water from $533.26 \mathrm{mg} / \mathrm{L}$ at location II to $0.03 \mathrm{mg} / \mathrm{L}$ at location III. On point location III, the variables almost qualified to the water quality standard (except the $\mathrm{pH}$ ) so could be said that the wastewater variables were good. Further, the wastewater was flown into the river.

The wastewater from storage pond was then mixed with the water from the ditch at point location IV, the concentration of the contaminant material was further decreased (Table 3). The mixing of wastewater with water would cause the dilution effect that would increase the DO and decrease the concentrations of TDS, BOD, COD, and ammonium. This observation showed that the receiving water body of the river not significantly impacted the water quality. This implication was evident from the variables result of the water river in a little part towards the upstream which has a slightly different from the point location of the outlet (Table 3 ).

The same values of ammonia $(0.02 \mathrm{mg} / \mathrm{L})$ detected at points locations IV and V showed that the wastewater disposal was not relatively influencing and increasing ammonia in the ditch. In contrast, the concentration of TDS, BOD, COD, and $\mathrm{pH}$ were decreased at the outlet point location. The results are suspected to be caused by the additional organic materials from the wastewater disposal. The wastewater was also detected to contain $E$. coli and coliform but still within the levels and amount of quality standard. Salmonella $s p$ were not detected so that there was no concern of pathogen contaminant around PT. B.

PT. C locates in Lampung and is owned by private. The wastes management was relatively out of date using the traditional handling. The feces collected were reused as a raw manure. The wastewater was derived from urine and dirty water used for washing the cage. Sampling points were four locations because the water channel (far from the cage close to the outlet) only had a few logged of water. The result showed that most of water variables measured exceeded the levels of quality standard. Only BOD and COD in point location II that were under the quality standard. The under standard qualities of BOD and COD were caused by the organic material on storage pond with a swamp-like design was absorbed by the water plants. According to Abdel-Raouf et al. (2012) and Sahu (2014), water plants were able to largely absorb the inorganic material, specially $\mathrm{P}$ and $\mathrm{N}$ as was shown in the reduction of BOD and COD at the point location far from the wastewater input.

In this AQI, the cages used the dry bottom system by coating with husks. The high result of COD (with almost $3000 \mathrm{mg} / \mathrm{L}$ ) in point location I was caused by the treatment of cattle with trembolon and antibiotics which then would be released in the urine. Australia as the only exporter of cattle to Indonesia is known to still use growth hormone. Research conducted by Danial et al. (2010) showed that all of urine samples (60 samples) of slaughter cattle imported from Australia were positive with variation in the concentrations of TBA residues. The concentrations of residual TBA $<2 \mathrm{ppb}$ were detected in 37 samples $(61.67 \%)$, the residual concentration of TBA ranged 2-4 ppb were detected in 7 samples $(7 \%)$, and the concentration of residual TBA $>4 \mathrm{ppb}$ were detected in 16 samples (26.67\%). Research conducted by Ezzariai et al. (2018) showed that the concentrations of antibiotics ranged from 1 to $136,000 \mu \mathrm{g} / \mathrm{kg}$ of dry matter in sludge and manure, representing a potential risk for the human health and the environment.

Similar reason was stated for the high result of ammonia with $80 \mathrm{mg} / \mathrm{L}$ in the samples measured. The wastewater relatively did not pollute the receiving water body because it had the phytoremediation treatment. However, the significant increase in COD at the outlet river point was suspected to be caused by the hard-todegrade material which had existed earlier. The reason was acceptable because the COD at the upstream (sampling point IV) were lower up to $328.61 \mathrm{mg} / \mathrm{L}$.

PT. D locates in South Tangerang and is owned by private. The wastes management handling was very out of dated. The feces was directly cleaned by flushing using water that was then pooled in the storage pond. The wastes were handled simply by using an aeration system inside the storage pond before discharged into the river. Water variables of $\mathrm{pH}, \mathrm{DO}$, TSS BOD, COD, and ammonia at point locations I and II exceeded the standard quality. The high results would contribute to the significant contamination of the river.

The result in Table 5 (point location V) also showed that the quality of the water river was not good and contaminated by the organic materials. This condition was 
caused by the location of the study area which was in the downstream area where would receive various types of pollutants from its upstream (Cordova \& Riani, 2011). The point location was downstream from Jabodetabek that was commonly heavy contaminated. This condition was getting worse after being mixed with the wastewater as was shown by the increase concentrations of BOD, $\mathrm{COD}$, and ammonia in the river. The low $\mathrm{pH}$ value is thought to be more influenced by the tides because the area is close to the river mouth (estuary). The wastewater was highly detected for E. coli and coliform and the numbers far exceeded the quality standard because the wastewater was mixed with the feces in a large quantity. Salmonella $s p$ was not detected so that there was no concern of pathogen contaminant around PT. D.

PT. E locates in Bogor and is owned by private. The wastes were handled with a simple process. The feces was collected for reuse as a raw manure. The wastewater was derived from urine and dirty water from the washing of the cage. PT.E discharges the wastewater directly into the ditch without any process. Sampling point was performed in 3 locations, all of the 3 sampling point locations were inside the storage pond because the water channel was directly out into the ditch. The cages used the dry bottom system which was coated with husks. Table 6 showed that the value of $\mathrm{pH}$, TSS, BOD, and COD exceeded the standard quality. Even when the wastewater meet the water from the ditch, they still expected to give a significant effect. This assumption was confirmed by the high $\mathrm{pH}$, TSS, BOD, and COD variables in point location III which were far above the quality standard. In contrast, the concentration of ammonia decreased in point location III. The decrease in the concentration of ammonia in the samples measured in this location was caused by the nonexistence of fecess in the wastewater. The fecess in the cage was taken and collected directly and used for sale by the workers. The amount of feces to be decomposed was not much, but the contribution to pollution should still be a serious concern, so that it will not burden the water in the future.

The wastewater was also detected for E. coli and coliform in the levels within the standard quality. This normal result is related to the possibility of feces contamination into the urine and the floor. Just like any others AQI where this research conducted, in PT. E Salmonella $s p$ were not detected. This nondetected Salmonella does not mean that pathogen bacteria are not found in the AQI wastewater. The nondetected Salmonella may be due to samples taken does not contain pathogen bacteria. According to Hilbert et al. (2012), Non Typhoidal Salmonella has a broad range of animal hosts, including cattle. Salmonella and Listeria monocytogenes are major food-borne pathogens that can be isolated from the feces of apparently healthy ruminants (Dhama et al., 2015).

\section{CONCLUSION}

The results of wastewater variables from largeruminant AQI activity are generally exceeding the Quality Standard of Wastewater for cattle-farming. From the 5 companies where research is conducted, there is no difference in pollution of temperature, DO, TDS, TSS, COD, and ammonia variables, but there were differences in $\mathrm{pH}$ and BOD variables. In term of environmental variables, the best situation is seen in PT B and the worst situation is seen in PT. E even with a contrasting $\mathrm{pH}$ value. The type of waste treatment at the company greatly determines the quality of AQI wastewater. Salmonella sp bacteria are undetected in the wastewater from AQI. This does not mean that pathogen bacteria are not found in the AQI wastewater, this may be due to samples taken does not contain pathogen bacteria.

\section{CONFLICT OF INTEREST}

There is no conflicts of interest associated with any financial, personal or other relationships with other people or organization related to the material discussed in this article.

\section{REFERENCES}

Abdel-Raouf, N., A. A. Al-Homaidan, \& I. B. M. Ibraheem. 2012. Microalgae and wastewater treatment. Saudi J. Biol. Sci. 19:257-275. https://doi.org/10.1016/j.sjbs.2012.04.005

Amalia, F., K. Nirmala, E. Harris, \& T. Widiyanto. 2014. Kemampuan Lemna (Lemna perpusilla Torr) sebagai fitoremediator untuk menyerap limbah nitrogen dalam budidaya ikan lele (Clarias Gariepinus) di system resirkulasi. Limnotek. 21:185-192.

Barantan (Badan Karantina Pertanian). 2017. Data Importasi Sapi Tahun 2013-2016. Jakarta.

Bartelt-Hunt, S., D. D. Snow, T. Damond-Powell, \& D. Miesbach. 2011. Occurrence of steroid hormones and antibiotics in shallow groundwater impacted by livestock waste control facilities. J. Contam. Hydrol. 123:94-103. https://doi.org/10.1016/j.jconhyd.2010.12.010

Borguini, R.G., D. H. M. Bastos, J. M. M. Neto, F. S. Capasso, \& E. A. F. S. Torres. 2013. Antioxidant potenstial of tomatoes cultivated in organic and conventional systems. Braz. Arch. Biol. Technol. 56:521-529. https://doi.org/10.1590/ S1516-89132013000400001

Cordova, M. R. \& E. Riani. 2011. Konsentrasi logam berat $(\mathrm{Hg}, \mathrm{Cd}, \mathrm{Pb})$ pada air dan sedimen di muara sungai angke, Jakarta. Jurnal Hidrosfir Indonesia Pusat Teknologi Lingkungan BPPT. 6:107-112 .

Damanik, L.H. 2014. Pemanfaatan feses ternak sapi sebagai energi alternatif biogas bagi rumah tangga dan dampaknya terhadap lingkungan. J. Teknosains. 4:1-102. https://doi. org/10.29244/avi.3.2.70-76

Danial, R., H. Latif, \& A. Indrawati. 2015. Deteksi residu hormon trenbolone acetat pada sapi siap potong impor asala Australia. Acta Veterinaria Indonesiana. 3: 70-76.

Deb, S. K. \& M. K. Shukla. 2011. A review of dissolve organic matter transport processes affecting soil and environmental quality. J. Environment Analytic Toxicol. 1: 1-11. https://doi.org/10.4172/2161-0525.1000106

Delahoy, M. J., B. Wodnik, L. McAlliley, G. Penakalapati, J. Swarthout, M. C. Freeman, \& K. Levy. 2018. Pathogen transmitted in animal feces in low-and middle-income countries. Int. J. Hyg. Environ. Health. 221:661-676. https:// doi.org/10.1016/j.ijheh.2018.03.005

Dhama, K., K. Karthik, R. Tiwari, M. Z. Shabbir, S. Barbuddhe, S.V.S. Malik, \& R. K. Singh. 2015. Listeriosis in animals, its public health significance (food-borne zoonosis) and advances in diagnosis and control: a comprehensive review. Vet. Q. 35:211-235. https://doi.org/10.1080/01652176 .2015.1063023 
El Kheir, W.A., G. Ismail, A. El-Nour, T. Tawfik, \& D. Hammad. 2007. Assesment of the efficiency of duckweed (Lemna gibba) in wastewater treatment. International Journal of Agriculture and Biology 5:681-689.

Ezzariai, A., M. Hafidi, A. Khadra, Q. Aemig, L. El Fels, M. Barret, G. Merlina, D. Patureau, \& E. Pinelli. 2018. Human and veterinary antibiotics during composting of sludge or manure: Global perspectives on persistence, degradation, and resistance genes. J. Hazard Mater. 359:465-481. https:// doi.org/10.1016/j.jhazmat.2018.07.092

Givens, C. E., D. W. Kolpin, M. A. Borchardt, J. W. Duris, T. B. Moorman, \& S. K. Spencer. 2016. Detection of Hepatitis $\mathrm{E}$ virus and other livestock-related pathogen in IOWA streams. Sci. Total Environ. 566: 1042-1051. https://doi. org/10.1016/j.scitotenv.2016.05.123

Goeppert, N., I. Dror, \& B. Berkowitz. 2014. Detection, fate and transport of estrogen family hormones in soil. Chemosphere. 95: 336-345. https://doi.org/10.1016/j. chemosphere.2013.09.039

Hilbert, F., F. J. M. Smulders, R. Chopra-Dewasthaly, \& P. Paulsen. 2012. Salmonella in the wildlife-human interface. Food Research Int. 45:603-608. https://doi.org/10.1016/j. foodres.2011.08.015

Ho, YB., M. P. Zakaria, P. A. Latif, \& N. Saarri. 2012 Simultaneious determination of veterinary antibiotics and hormone in broiler manure, soil and manure compost by liquid chromatography-tandem mass spectrometry. J. Chromatogr. A. 1262: 160-168. https://doi.org/10.1016/j. chroma.2012.09.024

KLHK (Kementrian Lingkungan Hidup) . 2014. Peraturan Menteri Lingkungan Hidup Nomor 5 tahun 2014 tentang Baku Mutu Air Limbah.
KLHK (Kementrian Lingkungan Hidup dan Kehutanan). 2001. Peraturan Menteri Lingkungan Hidup dan Kehutanan Nomor 82 Tahun 2001 tentang Kualitas Air dan Pengendalian Pencemaran.

Lange, I. G., A. Daxenberger, B. SchiVer, H. Witters, D. Ibarreta, \& H. D. D Meyer. 2002. Sex hormones originating from diVerent livestock production systems: Fate and potential disrupting activity in the environment. Anal. Chim. Acta. 473:27-37. https://doi.org/10.1016/S0003-2670(02)00748-1

Mansyur \& H. L. Choi. 2011. Change of physico-chemicals properties of pig slurry during storage. Med. Pet. 34:179183. https://doi.org/10.5398/medpet.2011.34.3.179

Pinheiro, A., R. M. R. Albano, T. C. Alves, V. Kaufmann, M. R. da Silva. 2013. Veterinary antibiotics and hormones in water from application of pig slurry to soil. Agric. Water Manag. 129:1-8. https://doi.org/10.1016/j. agwat.2013.06.019

Sahu, O. 2014. Reduction of organic and inorganic pollutant from waste water by algae. International Letters of Natural Sciences 8: 1-8. https://doi.org/10.18052/www.scipress. com/ILNS.13.1

Stehfest, E., M. V. D. Berg, G. Woltjer, S. Msangi, \& H. Westhoek. 2013. Option to reduce the environmental effect of livestock production-comparison of two economic models. Journal Agricultural Systems 114:38-53. https:// doi.org/10.1016/j.agsy.2012.07.002

Sutrisno, E., S. Sumiyati, \& Nurdiansyah. 2010. Pengaruh tanaman rumput bebek (Lemna minor) terhadap penurunan BOD dan COD. Jurnal Presipitasi 7:187x.

Tilahun A, I. Tameto, A. Teshale, A. Tafere, \& T. Hadush. 2016. Review on growth hormone in animals. Advances in Life Science and Technology 46:70-79. 